\title{
EFFECT OF CUT TYPE ON FRESH-CUT 'MENINA BRASILEIRA' ZUCCHINI QUALITY
}

\author{
Efeito do tipo de corte na qualidade de abobrinha 'Menina Brasileira' minimamente processada
}

\author{
Brígida Monteiro Vilas Boas ${ }^{1}$, Juliana Alvarenga Alves ${ }^{2}$, Eduardo Valério de Barros Vilas Boas ${ }^{3}$
}

\begin{abstract}
Market sales of ready-to-use fresh fruit and vegetables have grown quickly in the recent years as a result of changes in consumer attitudes. The goal of this work was to evaluate the effect of two kinds of cuts on the physiological, physical, physical-chemical, chemical and biochemical traits of fresh-cut 'Menina Brasileira' zucchini stored in rigid polypropylene packages, with lids of the same material containing sliced and grated zucchini and stored at $5^{\circ} \mathrm{C}$, for 15 days. The variables respiratory rate, $\mathrm{pH}, \mathrm{L}^{*}$ value, soluble pectin, PME and PG activity, was interactively affected by the cut type and storage time factors. The variables mass loss, phenylalanine ammonia-lyase activity and total pectin variable were only significantly affected by storage time factor. It can be concluded that sliced 'Menina Brasileira' zucchini shows a higher titratable acidity and soluble solids and a lower respiratory rate, pectin soluble and phenylalanine ammonia-lyase activity when compared with grated zucchini, contributing to the preservation of quality attributes.
\end{abstract}

Index terms: Cucurbita moschata, quality, storage.

\section{RESUMO}

As vendas no mercado de frutas e hortaliças frescas prontas para o consumo têm crescido rapidamente nos últimos anos como resultado de mudanças nas atitudes dos consumidores. Neste trabalho objetivou-se avaliar o efeito de dois tipos de cortes nas características fisiológicas, físicas, químicas, físico-químicas e bioquímicas de abobrinha 'Menina Brasileira' minimamente processada, armazenada a $5^{\circ} \mathrm{C}$ em embalagens de polipropileno rígido, com tampas do mesmo material, contendo abobrinha fatiada e ralada, por 15 dias. As variáveis taxas respiratórias, $\mathrm{pH}$, valor L*, pectina solúvel, atividade de PME e PG, foram interativamente afetadas pelos fatores tipo de corte e tempo de armazenamento. As variáveis perda de massa, atividade da fenilalanina amônia-liase e a pectina total foram afetadas significativamente apenas pelo fator tempo de armazenamento. Pode-se concluir que a abobrinha 'Menina Brasileira' fatiada apresentou uma maior acidez titulável e sólidos solúveis e uma menor taxa respiratória, pectina solúvel e atividade da fenilalanina amônia-liase, em comparação com abobrinha ralada, contribuindo para a preservação dos atributos de qualidade.

Termos para indexação: Cucurbita moschata, qualidade, armazenamento.

(Received in may 6, 2011 and approved in june 27, 2011)

\section{INTRODUCTION}

Changes in food consumption patterns have led to an increase consumption of fruits and vegetables rather than processed products, as consumers search for healthy foods that have adequate quality and practicality (ALVES et al., 2010a).

Minimally processed fruits and vegetables are defined as products that have been peeled, cut, sanitized and packed as a $100 \%$ usable product. These minimally processed fruits and vegetables offer consumers highly nutritious, convenient and healthy products, maintaining the freshness that people want in their food (IFPA, 2006).

Zucchini (Cucurbita moschata) is a fruit harvested immature, belonging to the Cucurbitaceae family. When it is left on the plant, the fruit develops the form of a mature pumpkin. The fruit is an easily digestible source of B vitamins such as niacin (FILGUEIRAS, 2000, LANA et al.,
2006). Zucchini is well appreciated by consumers and is used in various cooking methods, such as sautéed in oil and breaded and fried. Offering a minimally processed product increases their convenience and practicality in meal preparation, making them a more attractive purchase.

The most important characteristic of plant products after harvest is the fact that they are living organs and thus undergo active metabolic functions (CHITARRA; CHITARRA, 2005). The minimum process promotes a marked increase in the respiratory rate of plant products stemming from the damage caused to the tissues when cut. The physiology of minimally processed fruits and vegetables is essentially that of an injured tissue. This type of processing, involving peeling, slicing, among others, differs from traditional processing because the tissue remains viable (or fresh) during subsequent handling. Thus, the tissue behavior is generally typical of

${ }^{1}$ Instituto Federal de Educação, Ciência e Tecnologia do Sul de Minas Gerais - Machado - MG - Brasil

Universidade Federal de Lavras/UFLA - Departamento de Ciência dos Alimentos/DCA - Cx. P. 3037 - 37200-000 - Lavras - MG - Brasil juliana_alvarenga@yahoo.com.br

${ }^{3}$ Universidade Federal de Lavras/UFLA - Departamento de Ciência dos Alimentos/DCA - Lavras - MG - Brasil

Ciênc. agrotec., Lavras, v. 35, n. 6, p. 1178-1185, nov./dez., 2011 
that observed in tissues that have been injured or exposed to stress conditions, including increased respiration and ethylene production, and in some cases, induction of wound healing processes (BRECHT, 1995).

According to Cantwell and Suslow (2002), the greater the processing degree, the higher the rate of induced respiration. The high respiratory activity indicates a more active metabolism, and usually a faster deterioration rate, and may also result in faster loss of acids, sugars and other components that determine flavor quality and nutritional value.

The aim of this study was to evaluate the effect of two types of cuts (sliced and grated) on physiological, physical, physical-chemical, chemical and biochemical traits of freshcut 'Menina Brasileira' Zucchini stored at $5^{\circ} \mathrm{C}$ for 15 days.

\section{MATERIAL AND METHODS}

'Menina Brasileira' zucchini from the Central Supply Minas Gerais S/A (CEASA-MG), Contagem, MG were purchased at local markets in Lavras-MG, Brazil, with no injuries. The fruits were transported to the Postharvest Fruit and Vegetable Laboratory, Food Science Department, Federal University of Lavras, Lavras, MG.

The zucchinies were washed in water with detergent and then sanitized in a solution of sodium dichloroisocyanurate $100 \mathrm{mg} \mathrm{L}^{-1}$ for 15 minutes and dried at $18^{\circ} \mathrm{C}$. Only the "neck" of the fruit was manually sliced in the transverse direction ( $5 \mathrm{~mm}$ thick), with the help of sharp stainless steel knife, and shredded by hand (strips $5 \mathrm{~mm}$ wide and $4 \mathrm{~cm}$ in length) in a household plastic grater. The sliced and grated zucchini were immersed in a solution of sodium dichloroisocyanurate $100 \mathrm{mg} \mathrm{L}^{-1}$ for 5 minutes, and soon after were placed in a plastic sieve to remove excess water present in the product. Then, they were packed in rigid polypropylene $(15 \times 11.5 \times 4.5 \mathrm{~cm})$ with a hard cover of the same polymer. The packages containing the product were stored cold $\left(5^{\circ} \mathrm{C} \pm 1^{\circ} \mathrm{C}\right.$ and $\left.90 \pm 5 \% \mathrm{RH}\right)$ for 15 days and the analysis of the following performed every 3 days:

\section{Respiration rate $\left(\mathrm{mL} \mathrm{CO} \mathrm{kg}^{-1} \mathrm{~h}^{-1}\right)$}

The grated zucchini as well as sliced (about $100 \mathrm{~g}$ ) were placed in glass flasks $(580 \mathrm{~mL})$ with plastic cap containing a silicone septum, through which a portion of the internal atmosphere was withdrawn with the aid of a PBI Dansensor gas analyzer, which measures the percentage of oxygen and carbon dioxide $\left(\mathrm{CO}_{2}\right)$. The $\mathrm{CO}_{2}$ percentages were used to calculate the respiratory rate, considering the volume of the flask, the mass of the product and the time the flask remained closed (90 minutes). After reading, the flasks were wrapped with micro-perforated polyvinyl chloride film ( $0.014 \mathrm{~mm}$ thick).

\section{Weight loss (\%)}

Calculated as the difference between the initial mass of sliced and grated zucchini contained in the packages and obtained at each time interval, using a Mettler semianalytical balance model PC2000.

\section{Titratable acidity (volume required, in $\mathrm{mL}$ of $\mathrm{NaOH}$ )}

Performed by titration with $0.01 \mathrm{~N} \mathrm{NaOH}$, with phenolphthalein as indicator, according to Instituto Adolfo Lutz (1985).

pH

A TECNAL (Tec 3MP) pH meter was used, according to AOAC (2005).

\section{Soluble solids ( $\left.{ }^{\circ} \mathrm{Brix}\right)$}

An Atago PR100 digital refractometer was used, with automatic temperature compensation, at $25^{\circ} \mathrm{C}$ (AOAC, 2005).

Evaluations of titratable acidity, soluble solids and $\mathrm{pH}$ were made in filtered homogenate, after grinding the product in a tissue homogenizer at a proportion 1:5 (product: water).

\section{L*value}

The readings were taken on opposite sides in the center of five slices of zucchini and five random points, directly on the surface of grated zucchini contained in the container, using a Minolta colorimeter, model CR 400, with illuminant D65 and CIEL*a*b* color system (MINOLTA, 1998).

\section{Total and soluble pectin (mg galacturonic acid. $100 \mathrm{~g}^{-1}$ )}

Extracted according to McCready; McComb (1952) and the levels determined colorimetrically, according to Bitter; Muir (1962).

\section{Pectin methylesterase activity}

The extraction was performed according to Buescher; Furmanski (1978), with modifications by Vilas Boas et al. (1996) and the dosage according to Hultin et al. (1966) and Ratner et al. (1969), with modifications by Vilas Boas et al. (1996). The unit of enzyme activity was defined as the amount of enzyme capable of catalyzing the demethylation of pectin related to the consumption of 1nanomol NaOH.min ${ }^{-1} \mathrm{~g}^{-1}$, under the test conditions.

\section{Poligalacturonase activity}

Extraction was performed according to Buescher; Furmanski (1978), with modifications by Vilas Boas et al. (1996) and the dosage was done according to Markovic et al. (1975), with modifications by Vilas Boas et al. (1996). 
The enzyme activity was expressed in nanomol galacturônico.min acid $\mathrm{g}^{-1}$.

\section{Phenylalanine ammonia-lyase activity}

Extraction was done based on the technique advocated by Rhodes; Wooltorton (1971). The enzyme activity was expressed in $\mathrm{U} \mathrm{min}^{-1} \mathrm{~g}^{-1}$, defined as the content of enzyme that produces an increase in absorbance at 290 nm of 0.01 per minute (ZUCKER, 1965).

The experiment was conducted in a completely randomized design with three replications. Treatments were arranged in a 2 x 6 factorial, the factors being type of cut (sliced and grated) and storage time (0, 3, 6, 9, 12 and 15 days). The experimental plot consisted of a package containing about $105 \mathrm{~g}$ and $130 \mathrm{~g}$ of sliced and grated zucchini, respectively. Statistical analysis was performed using the Sisvar program (FERREIRA, 2008).

\section{RESULTSAND DISCUSSION}

Respiratory rate was interactively affected by the cut type and storage time factors. The respiratory activity of grated zucchini was higher than the sliced from the sixth day of storage (Figure 1A). The grated zucchini was subjected to great physical stress upon being cut, which increased its respiratory metabolism, visible from the sixth day. The respiration rate of fresh-cut products is generally higher than those found in whole fruits and vegetables, for example, the respiration rate of fresh-cut roots of radish slices are on average $95 \%$ higher than the respiration rate of whole roots when stored $5^{\circ} \mathrm{C}$ and $90 \% \mathrm{RH}$ for 10 days (SAAVEDRADELALGUILA et al., 2007). The greater the processing degree, the higher the induced respiration rate. The high respiration rates indicate a more active metabolism, and usually a faster deterioration rate (CANTWELL; SUSLOW, 2002). This behavior was also observed by Del Aguila et al. (2006) when studying the effect of different cuts on the quality of fresh-cut radishes.

The respiratory rate of grated zucchini increased sharply until the ninth day (40.08 to $92.19 \mathrm{mLCO}_{2} \mathrm{~kg}^{-1} \mathrm{~h}^{-1}$ ) (Figure 1A) in response to this type of cut, which was the most severe. But soon after, it remained constant until the end of storage $\left(91.78 \mathrm{~mL} \mathrm{CO}_{2} \mathrm{~kg}^{-1} \mathrm{~h}^{-1}\right)$, possibly due to the storage temperature used. We observed a less pronounced increase in the respiratory rate of sliced zucchini until the sixth day (43.15 to $57.27 \mathrm{~mL} \mathrm{CO}_{2} \mathrm{~kg}^{-1} \mathrm{~h}^{-1}$ ) and then a fall until the end of storage $\left(15.90 \mathrm{~mL} \mathrm{CO} \mathrm{kg}^{-1} \mathrm{~h}^{-1}\right)$. This decrease in respiratory rate is due to the low temperature $\left(5^{\circ} \mathrm{C}\right)$ that, in this case, was more effective in controlling the stress caused by this type of cut, thereby reducing the metabolism of the zucchini slices.

The mass loss variable was significantly affected only by storage time. The mass loss percentages of fresh cut zucchini increased during storage, not exceeding $0.7 \%$ (Figure 1B), due to storage temperature used and the barrier offered by the package. Alves et al. (2010b) also found also a gradual increase in mass loss of fresh-cut mangoes, not exceeding $0.5 \%$ during the storage. This loss is considered negligible, from a practical point of view. The fruits and vegetables, even when kept under ideal conditions, suffer some mass loss during storage due to the combined effect of respiration and transpiration (CHITARRA; CHITARRA, 2005).
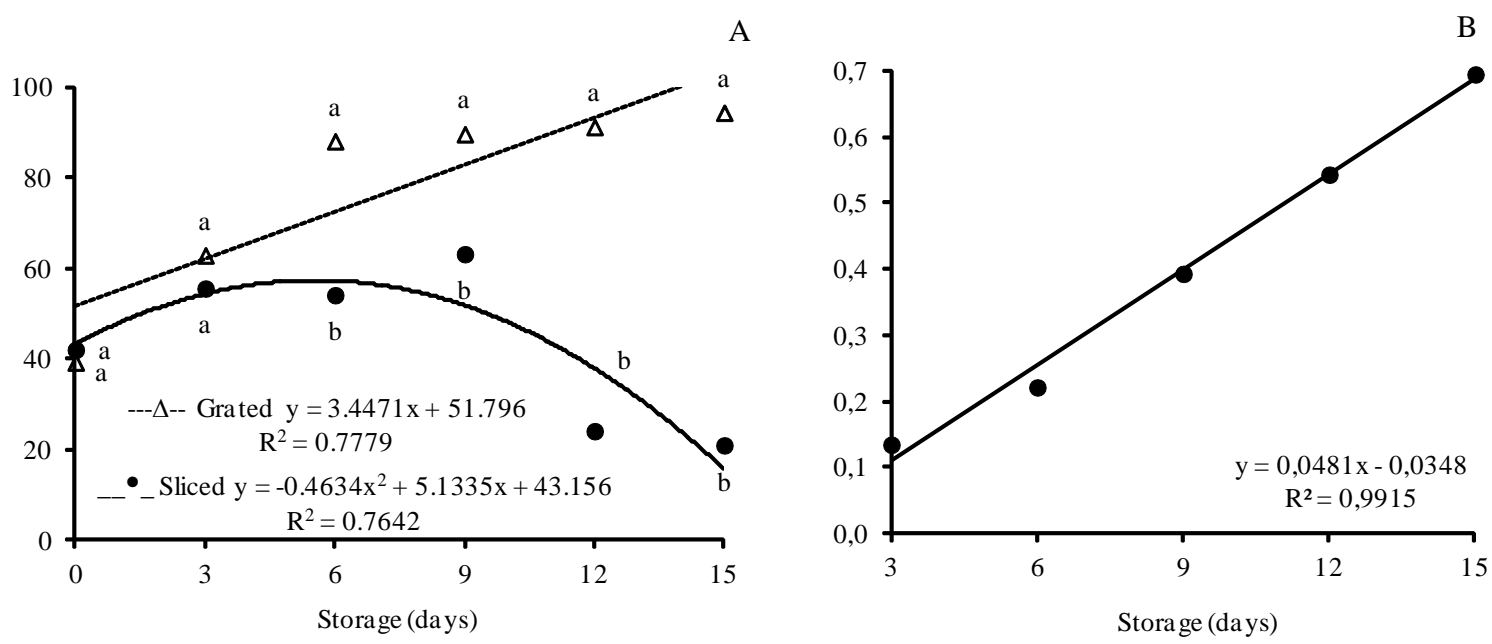

Figure 1 - Mean values, regression equation and coefficient of determination of respiratory rate (A) and weight loss (B) in freshcut 'Menina Brasileira' zucchini, subjected to two types of cuts (sliced and grated) and stored at $5 \pm 1^{\circ} \mathrm{C}$ and $90 \pm 5 \% \mathrm{RH}$ for 15 days. Means followed by same letter within each time are not statistically different from each other by the Tukey test at $5 \%$. 
The acidity variable was only significantly influenced by the type of cut factor. The acidity levels $(0.52 \mathrm{~mL}$ of $\mathrm{NaOH} 0.01 \mathrm{~N})$ of grated zucchini were lower, statistically, than those of sliced zucchini $(0.66 \mathrm{~mL}$ of $\mathrm{NaOH}$ $0.01 \mathrm{~N}$ ). This is probably due to greater consumption of organic acids in the respiratory process, which was most notable in the grated zucchini (Figure 1A). Insofar as the respiration corresponds to the oxidative reactions of organic compounds that are transformed into water and carbon dioxide, with production of chemical energy used for biosynthesis of new compounds essential to the smooth operation and maintenance of the plant product as a whole. Together with sugars, organic acids are used as respiratory substrate for the supply of carbon and energy production. As metabolic intermediates, they are found in small amounts in the cytosol because they get accumulated in the vacuole, where they represent an available source of stored energy (CHITARRA; CHITARRA, 2005).

There was a significant interaction between the type of cut and storage time factors for the $\mathrm{pH}$ variable. The $\mathrm{pH}$ of sliced zucchini was below that of grated zucchini from the sixth day on (Figure 2). The sliced zucchini showed lower $\mathrm{pH}$ and hence higher acidity. The $\mathrm{pH}$ of grated zucchini increased linearly from 6.16 to 6.71 , during storage. The $\mathrm{pH}$ of the sliced remained almost stable up to the ninth day (6.28 to 6.25) and then rose until the end of storage (6.56). These results bear out the consumption of organic acids by the respiratory process, which was more intense in the grated zucchini (Figure 1A).

There was no significant interaction between the type of cut and storage time factors for the soluble solids variable, only an isolated effect of the cut type. The grated zucchini suffered the greatest injury on being cut, resulting in a higher metabolism, which can be evidenced by the increased respiratory activity. Thus, consumption of respiratory substrates was more intense, so the soluble solids were lower $\left(1.4^{\circ}\right.$ Brix $)$, statistically, than the sliced (2.4 ${ }^{\circ}$ Brix).

The lower titratable acidity, the lower soluble solids content and higher $\mathrm{pH}$ observed in the grated zucchini can also be associated; however, to a lesser extent, to the removal of cellular contents leaked during the sanitization step performed after cut.

The $\mathrm{L}^{*}$ value indicates how bright or how dark the product is, ranging from zero (totally black) to one hundred (completely white). The $\mathrm{L}^{*}$ value was significantly influenced by the interaction between the type of cut and storage time factors. The statistical differences observed between the $\mathrm{L}^{*}$ values of sliced and grated zucchini (Figure $3 \mathrm{~A}$ ), were attributed to the type of cut and the manner of determination, which in the case of sliced zucchini, was conducted only in the center of the yellow-greenish pulp, with no interference from the green skin color. In this case, we chose to discuss only the behavior of the $\mathrm{L} *$ value during the storage.

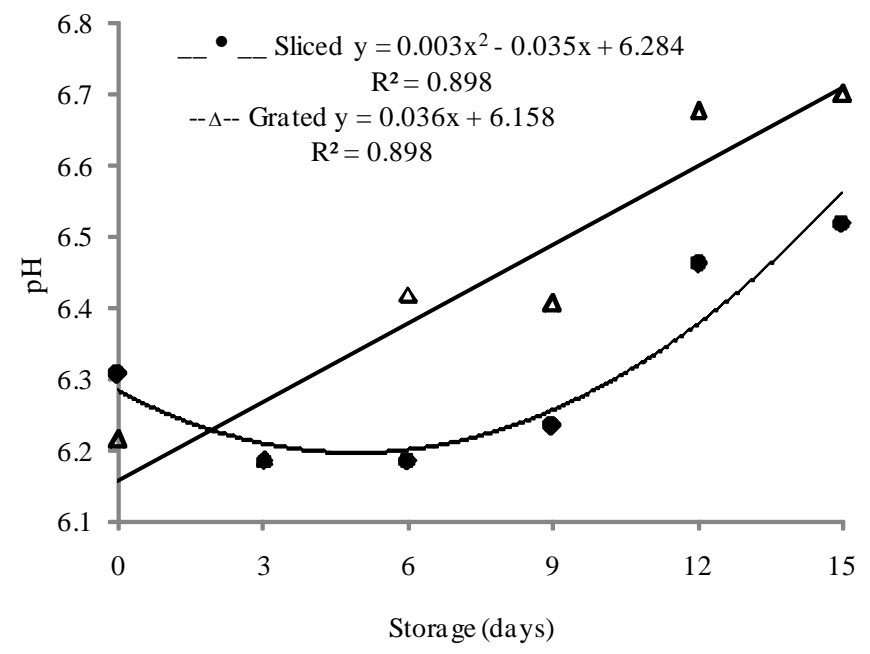

Figure 2 - Mean values, regression equation and coefficient of determination of $\mathrm{pH}$ in fresh-cut 'Menina Brasileira' zucchini, subjected to two types of cuts (sliced and grated) and stored at $5 \pm 1^{\circ} \mathrm{C}$ and $90 \pm 5 \%$ humidity for 15 days. Means followed by same letter within each time are not statistically different from each other by the Tukey test at $5 \%$. 
Time in storage did not affect the $\mathrm{L}^{*}$ value of sliced zucchini (Figure 3A), which was an average of 83.89, possibly due to less stress caused by the cut, compared with the grated zucchini and also the effectiveness of the temperature in controlling responses induced by this cut. The $\mathrm{L}^{*}$ value of the grated zucchini increased with the storage, from 63.98 to 71.58 , making it lighter, or whitish (Figure 3A). This probably occured due to the deposition of lignin on the surface of the cut area, which is related to wound healing processes.

Similar results were observed in fresh-cut carrots, in which the metabolism of phenylpropanoids was activated after injury, inducing the lignification process on the cut surface (BOLIN; HUXSOLL, 1991, HOWARD; GRIFFIN, 1993). This physiological response has been proposed as a cause of the whitening of fresh-cut carrots. The other cause is related to surface dehydration, which is a physical response (CISNEROS-ZEVALLOS et al., 1995), but it was not apparently observed in this work, as the mass loss was minimal during storage (Figure 1B ).

The phenylalanine ammonia-lyase (PAL) activity variable was significantly influenced by cut type and storage time factors. The grated zucchini showed higher PAL adivity (16.29 $\mathrm{Umin}^{-1} \mathrm{~g}^{-1}$ ) when statistically compared to the sliced $\left(10.10 \mathrm{U} \mathrm{min}^{-1} \mathrm{~g}^{-1}\right)$. This occurred in response to greater tissues damage caused by this type of cut.

PAL is considered a key enzyme for the phenylpropanoid route responsible for the biosynthesis of phenolic compounds, which gives origin to the lignin molecule. Thus, the fact that the grated zucchini tended to be white, due to the increased $\mathrm{L}^{*}$ value with the storage time (Figure 3A), may be related to increased PAL activity, once this enzyme is involved in lignin biosynthesis (HOWARD; GRIFFIN, 1993). Moreover, minimum processing promotes physical injuries and this enzyme should be linked to wound healing processes. Despite the significant effect of time, and no statistical adjustment for the variable activity of PAL, there was a small variation, from 12.10 to $13.99 \mathrm{U} \mathrm{min}^{-1} \mathrm{~g}^{-1}$, during the storage (Figure 3B).

The total pectin variable was only significantly influenced by the storage time factor. We observed pectin degradation in fresh-cut zucchini up to the third day and then the total pectin content remained practically constant until the end of storage (Figure 4A). The softening of the tissues is marked by changes in cell wall pectin, which are characterized by their depolymerization and solubilization.

The soluble pectin variable was significantly influenced by the interaction between the type of cut and storage time factors. The soluble pectin levels in the shredded zucchini were lower than those of the sliced, up to the third day of the storage (Figure 4B). This difference can possibly be due to the sanitizing step after cutting that promoted a higher removal of the cellular sap extravasated from the surface of grated zucchini, resulting in lower soluble pectin content. On the twelfth and fifteenth days of storage, the grated zucchini showed higher soluble pectin contents by virtue of its cell metabolism being faster, leading to changes in cell wall components, among them more pectic solubilization.
A

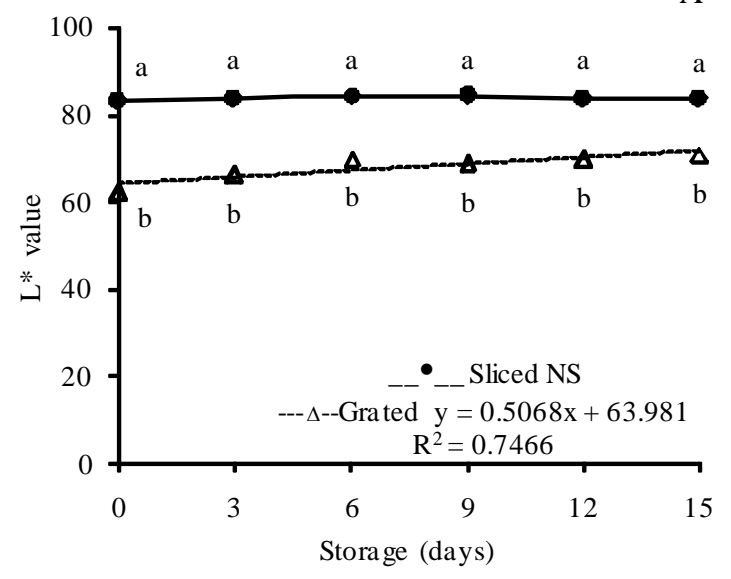

B

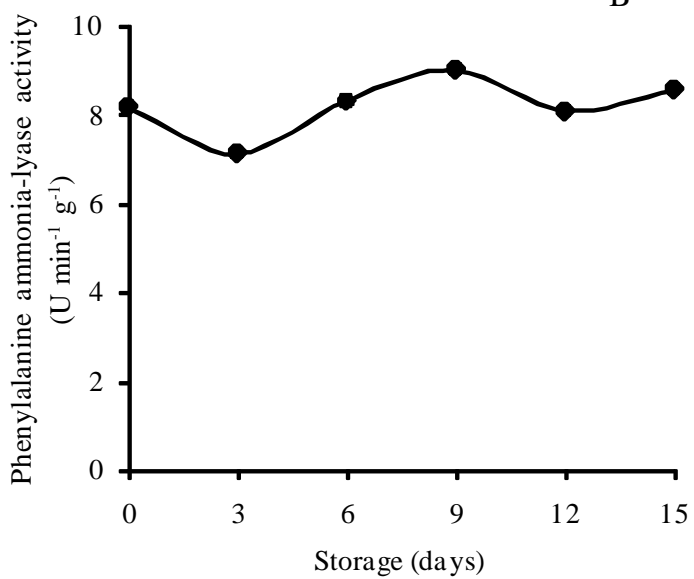

Figure 3 - Mean values, regression equation and determination coefficient of the $\mathrm{L} *$ value (A) and phenylalanine ammonia-lyase activity (B) in fresh-cut 'Menina Brasileira' zucchini, subjected to two types of cut (sliced and grated) and stored $5 \pm 1^{\circ} \mathrm{C}$ and $90 \pm 5 \% \mathrm{RH}$ for 15 days. Means followed by same letter within each time are not statistically different from each other by the Tukey test at $5 \%$.

Ciênc. agrotec., Lavras, v. 35, n. 6, p. 1178-1185, nov./dez., 2011 

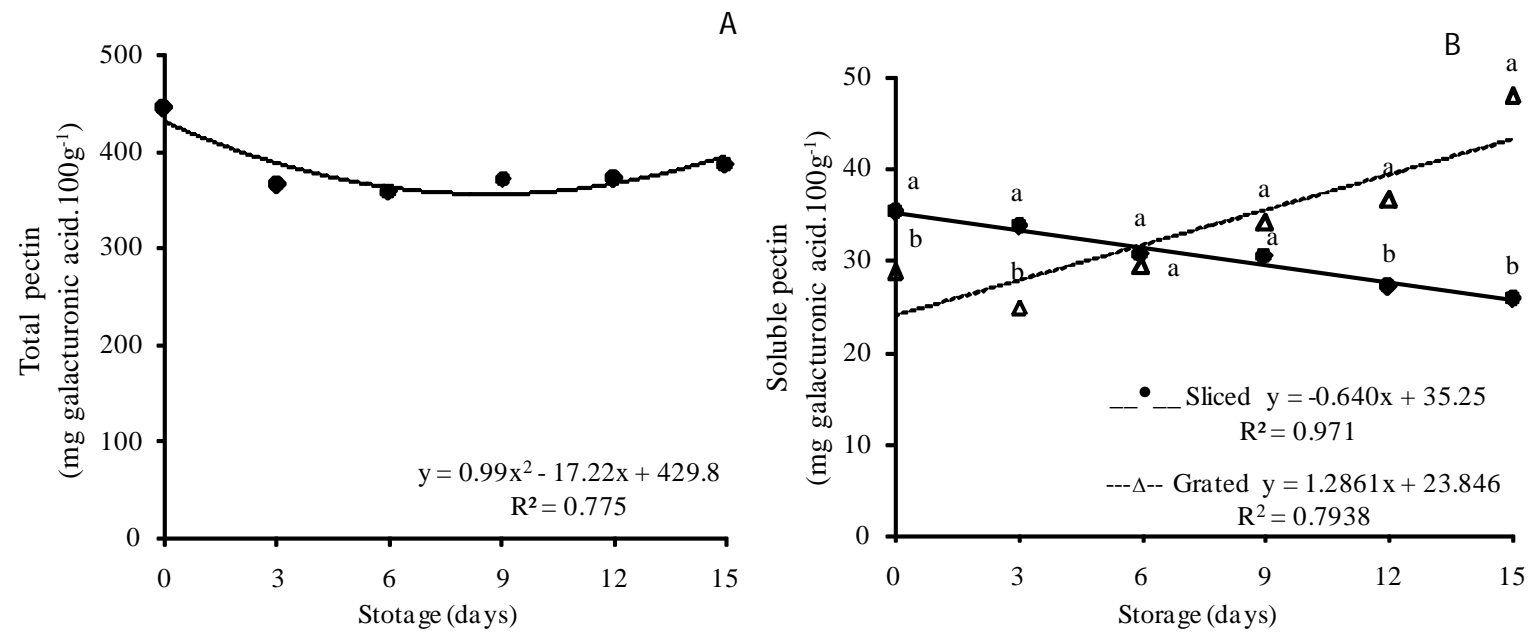

Figure 4 - Mean values, regression equation and coefficient of determination of total (A) and soluble (B) pectin in freshcut 'Menina Brasileira' zucchini, subjected to two types of cut (sliced and grated) and stored at $5 \pm 1^{\circ} \mathrm{C}$ and $90 \pm 5 \% \mathrm{RH}$ for 15 days. Means followed by same letter within each time are not statistically different from each other by the Tukey test at $5 \%$.

There was a linear increase in the levels of soluble pectin in the shredded zucchini with storage (Figure 4B), which contributed to the increase in pectin solubilization. However, the sliced zucchini tended to reduce the levels of soluble pectin in the course of storage, which may be related to less physical stress caused to the tissues when compared to grated. The slices of zucchini had lower levels of soluble pectin at the end of storage, indicating that slicing was more effective in retaining the pectin solubilization process as it contributed to the softening of tissue due to the reduction of the cohesion strength between cells.

There was a significant interaction between the type of cut and storage time factors for the pectin methylesterase (PME) and polygalacturonase (PG) activity. The PME activity of sliced zucchini was higher than for the grated, only on the ninth and twelfth days of storage (Figure 5A), an increase that naturally occurred in the immature fruit. The grated zucchini had statistically the highest PG activity by the sixth day, when compared to the sliced (Figure 5B). It is suggested that this activity was sufficient to cause an increase in pectin solubilization with storage (Figure 4B).

Storage time did not affect $\mathrm{PG}$ activity of zucchini slices. The low PG activity (Figure 5B) is related to lower pectin solubilization (Figure 4B) observed in the sliced zucchini in relation to the grated. The grated zucchini PG activity linearly decreased with storage, from 26.80 to 17.70 , even so, this enzyme was responsible for the pectin solubilization process. This activity loss trend may be associated with greater physical stress caused in the grated zucchini, responsible for cell membrane disruption, promoting greater activity of this enzyme on its substrate, with higher activity at time zero.

According to Vilas Boas (2007), the softening of tissues involves a coordinated action of cell wall enzymes, the PME, PG, beta-galactosidase and xyloglucanases being the most suggested. These enzymes act on the depolymerization and solubilization of pectin and hemicellulose, which culminate with the softening of tissues. Minimally processed fruits show faster softening than intact fruits. 

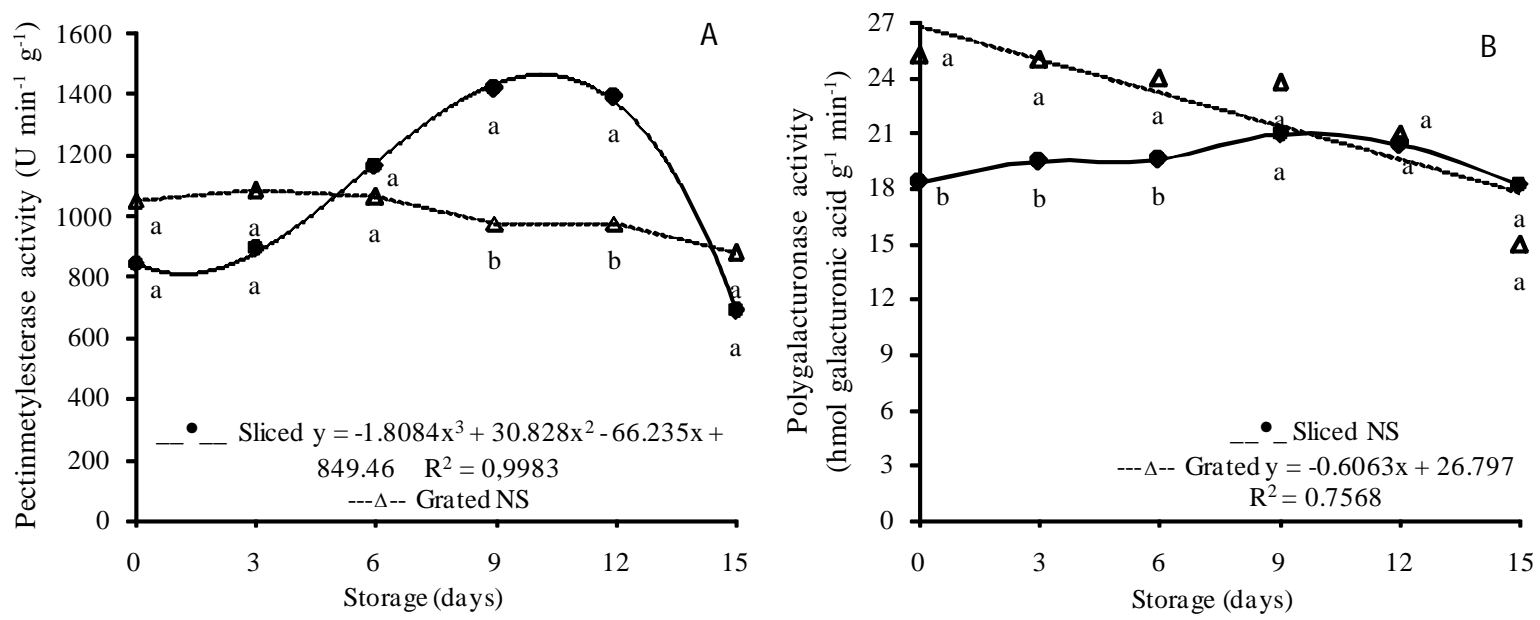

Figure 5 - Mean values, regression equation and coefficient of determination of pectin methylesterase (A) and polygalacturonase (B) activity in fresh-cut 'Menina Brasileira' zucchini, subjected to two types of cut (sliced and grated) and stored at $5 \pm 1{ }^{\circ} \mathrm{C}$ and $90 \pm 5 \% \mathrm{RH}$ for 15 days. Means followed by same letter within each time are not statistically different from each other by the Tukey test at $5 \%$.

\section{CONCLUSION}

Sliced 'Menina Brasileira' zucchini showed a lower respiratory rate, pectin soluble and phenylalanine ammonialyase activity when compared with grated zucchini, contributing to the preservation of quality attributes.

\section{ACKNOWLEDGEMENTS}

For the financial support granted by the National Council for Research and Develoment of Brazil (CNPq), to CAPES (Coordination for the Improvement of Higher Level - or Education - Personnel) and to FAPEMIG (Research Support Foundation of Minas Gerais State) for scholarship and credit support.

\section{REFERENCES}

ALVES, J.A. et al. Vida útil de produto minimamente processado composto por abóbora, cenoura, chuchu e mandioquinha-salsa, Ciência e Agrotecnologia, Lavras, v. 34, n. 1, p. 182-189, jan./fev., 2010a.

ALVES, J.A. et al. Cinética de degradação de vitamina c em mangas 'palmer' minimamente processadas armazenadas em diferentes temperaturas. Ciência e Agrotecnologia, Lavras, v. 34, n. 3, p. 714-721, maio/jun., 2010b.

\section{ASSOCIATION OF OFFICIALANALYTICAL} CHEMISTRY. Official methods of analysis of the Association of Official Analytical Chemistry. 18. ed. Maryland, 2005.
BITTER, T.; MUIR, H.M. A modified uronic acid carbazole reaction. Analytical Biochemistry, New York, v. 4, n. 4, p. 330-334, 1962.

BOLIN, H.R.; HUXSOLL, C.C. Control of minimally processed carrot (Daucus carota) surface discoloration caused by abrasion peeling. Journal Food Science, Chicago, v. 56, n. 2, p. 416-418, Mar./ Apr. 1991.

BRECHT, J.K. Physiology of lightly processed fruits and vegetables. HortScience, Alexandria, v. 30, n. 1, p. 18-22, Feb. 1995.

BUESCHER, R.W.; FURMANSKI, R.J. Role of pectinesterase and polygalacturonase in the formation of woolliness in peaches. Journal of Food Science, Chicago, v. 43, n. 1, p. 264-266, Jan./Feb. 1978.

CANTWELL, M.I.; SUSLOW, T.V. Postharvest handling systems: fresh-cut fruits and vegetables. In: KADER, A. A. (Ed.). Postharvest technology of horticultural crops. 3. ed. Davis: California, 2002. cap. 36, p. 445-463.

CHITARRA, M.I.F.; CHITARRA, A.B. Pós-colheita de frutas e hortaliças: fisiologia e manuseio. 2. ed. rev. e ampl. Lavras: UFLA, 2005. 785 p. 
CISNEROS-ZEVALLOS, L.; SALTVEIT, M.E.;

KROCHTA, J.M. Mechanism of surface white discoloration of peeled (minimally processed) carrots during storage. Journal of Food Science, Chicago, v.60, n.2, p.320-323, Mar./Apr. 1995.

DELAGUILA, J.S. et al. Fresh-cut radish using different cut types and storage temperatures. Postharvest Biology and Technology, Amsterdam, v.40, n.2, p. 149154, May. 2006.

FERREIRA, D.F. SISVAR: a program for statistical analysis and teaching. Symp. n.6, p.36-41, 2008.

FILGUEIRA, F.A.R. Novo manual de olericultura: agrotecnologia moderna na produção e comercialização de hortaliças. Viçosa: UFV, 2000. 402 p.

HOWARD, L.R.; GRIFFIN,L.E. Lignin formation and surface discoloration of minimally processed carrot sticks. Journal of Food Science, Chicago, v.58, n.5, p.1065-1067, Sept./Oct. 1993.

HULTIN, H.O.; SUN, B.; BULGER, J. Pectin methyl esterases of the banana. Purification and properties. Journal of Food Science, Chicago, v.31, n.3, p.320-327, May/June 1966.

IFPA. 2006. International fresh-cut produce association. Disponível em: <http://www.fresh-cuts.org>. Acesso em: 15 fev. 2006.

\section{INSTITUTO ADOLFO LUTZ. Normas analíticas,} métodos químicos e físicos para análise de alimentos. 3 . ed. São Paulo: Instituto Adolfo Lutz, 1985. v.1, 533 p.

LANA, M.M. et al. Abobrinha. Brasília, DF: Embrapa/ Hortaliças. In: <http://www.cnph.embrapa.br/paginas/ dicas_ao_consumidor/abobrinha.htm >. Acesso em: 18 out. 2006.

MARKOVIC, O.; HEINRICHOVÁ, K.; LENKEY, B. Pectolytic enzymes from banana. Collection
Czechoslovak Chemistry Community, London, v.40, p.769-774, 1975.

McCREADY, R.M.; McCOMB, E.A. Extraction and determination of total pectic materials in fruit. Analytical Chemistry, Washington, v.24, n.12, p.1586-1588, Dec. 1952.

MINOLTA. Precise color communication: color control from perception to instrumentation. Sakai, 1998. (Encarte)

RATNER, A.; GOREN, R.; MONSELINE, S.P. Activity of pectin esterase and cellulase in the abscission zone of citrus leaf explants. Plant Physiology, Washington, v.44, n.12, p.1717-1723, Dec. 1969.

RHODES, M.J.C.; WOOLTORTON, L.S.C. The effect of ethylene on the respiration and on the activity of phenylalanine ammonia lyase in swede and parship root tissue. Phytochemistry, Oxford, v.10, n.9, p.1989-1997, 1971.

SAAVEDRA DEL AGUILA, J. et al. Alteração do metabolismo respiratório em rabanetes minimamente processados. Ciência Rural, Santa Maria, v.37, p.565$568,2007$.

VILAS BOAS, E.V.de B.; CHITARRA, A.B.; CHITARRA, M.I.F. Modificações pós-colheita de banana 'Prata' gama irradiada. Pesquisa Agropecuária Brasileira, Brasília DF, v.31, n.9, p.599-607, 1996.

VILAS BOAS, E.V. de B. Processamento mínimo de kiwi. In: Moretti, C.L. (editor técnico). Manual de processamento mínimo de frutas e hortaliças. Brasília: EMBRAPA Hortaliças e SEBRAE, 2007. 531p. Capítulo 11.p.229-242.

ZUCKER, M. Induction of phenylalanine deaminase by light and its relation to chlorogenic acid syntesis in potato tuber tissue. Plant Physiology, Baltimore, v.40, n.5, p.779-784, Sept. 1965. 